\title{
Energy and economic evaluation of a solar assisted ground source heat pump system for a north Mediterranean city
}

\author{
Accepted for publication in Energy \& Buildings Wed, Nov 25, 2020
}

Evangelos I. Sakellariou ${ }^{\text {a.* }}$, Petros J. Axaopoulos ${ }^{a}$, Andrew J. Wright ${ }^{b}$

${ }^{a}$ University of West Attica. Department of Mechanical Engineering. Campus II. Thivon 250. 12241 Aegaleo. Greece

${ }^{\mathrm{b}}$ De Montfort University. Institute of Energy and Sustainable Development. The Gateway. Leicester LE1 9BH. UK

Keywords: solar assisted system, PVT, life cycle cost, life cycle savings, borefield, energy performance metrics.

\section{E-mail addresses:}

evangelosenergy@gmail.com (E. Sakellariou)*, pax@uniwa.gr (P.Axaopoulos),

AWright@dmu.ac.uk (A.Wright)

\begin{abstract}
In this study, a PVT based solar assisted ground source heat pump (SAGSHP) system was investigated regarding its energy performance and cost-effectiveness for the city of Thessaloniki (Greece). The SAGSHP system was set up to cover the space heating and domestic hot water needs for a low-rise dwelling. A mathematic model of the system was formulated in TRNSYS was used with the aim to carry out parametric analysis by varying the number of the PVTs. Two of the most important components of the employed model, the PVT collector and the geothermal heat exchanger, have already been validated via experimental data. Simulations were conducted and through the results seven energy metrics were estimated, with the objective to examine the system's energy performance from various perspectives. The SAGSHP system with 16 PVTs was found capable of covering $73 \%$ of the heating load and to generate 1.22 times more electricity than that consumed by the system. The electricity yield of PVTs was not affected throughout the parametric analysis, and the maximum specific productivity was estimated at $301.5 \mathrm{kWh}_{\mathrm{e}} \mathrm{PVT}^{-1}$ per year. The results suggest that a SAGSHP system equipped with about 14 PVTs can reach energy self-sufficiency. As regards the economics of the SAGSHP system, this was compared with a natural gas boiler system via two methods: life cycle cost (LCC) and life cycle savings (LCS). A sensitivity analysis with major economic parameters of the systems was carried out. It was found that the cost-effectiveness of the SAGSHP system is influenced mainly by its capital cost and by the price of the natural gas. Systems equipped with less than 12 PVTs can be cost-competitive by subsiding from $8 \%$ up to $42 \%$ of their capital cost. Also, system with more than 12 collectors were found of more benefit than the smaller ones, in the case where feed-in-tariff schemes are applied, or the bank loan's interest rate is low. It can be concluded that, the proposed system can be an attractive monetary solution for covering the heating load in comparable dwellings with a similar climate to Thessaloniki.
\end{abstract}




\begin{tabular}{|c|c|c|c|}
\hline \multicolumn{2}{|c|}{ Nomenclature } & \multicolumn{2}{|c|}{ Abbreviations } \\
\hline $\mathrm{ACOH}$ & annualized cost of heat, $€ \mathrm{kWh}^{-1}$ & $B H E$ & borehole heat exchanger \\
\hline $\mathrm{Bi}$ & bank loan interest, $\%$ & $D H W$ & domestic hot water \\
\hline CC & capital cost, $€$ & $E E B$ & earth energy bank \\
\hline $\mathrm{CF}$ & cash flow, $€$ & $F P C$ & flat plate collector \\
\hline COP & coefficient of performance, - & GHE & geothermal heat exchanger \\
\hline E & electric energy, kWh & GSHP & ground source heat pump \\
\hline EP & imported electricity price, $€ \mathrm{kWh}^{-1}$ & $N G B$ & natural gas boiler \\
\hline FIT & feed-in-tariff, $€ \mathrm{kWh}^{-1}$ & $P P$ & periodic payment of bank loan \\
\hline $\mathrm{i}$ & inflation, \% & $P V$ & photovoltaic panel \\
\hline L & annual heating load, kWh [eq. 12] & PVT & photovoltaic and thermal collector \\
\hline LCC & life cycle cost, $€$ & SAGSHP & $\begin{array}{l}\text { solar assisted ground source heat } \\
\text { pump }\end{array}$ \\
\hline LCS & life cycle savings, $€$ & SAHP & solar assisted heat pump \\
\hline MC & maintenance cost, $€$ & \multicolumn{2}{|l|}{ Subscripts } \\
\hline $\mathrm{n}$ & number of PVT collectors, - & aux & auxiliary \\
\hline NP & natural gas price, $€ \mathrm{kWh}^{-1}$ & cond & condenser \\
\hline NPV & net present value, $€$ & EP & imported electricity \\
\hline PP & $\begin{array}{l}\text { periodic payment of bank loan, } € \\
\text { year }^{-1}\end{array}$ & ev & evaporator \\
\hline PVT_i & electricity generated by PVT, kWh & FIT & feed-in-tariff \\
\hline PVT_u & $\begin{array}{l}\text { electricity delivered to the power } \\
\text { grid, } \mathrm{kWh}\end{array}$ & $\mathrm{HP}$ & heat pump \\
\hline Q & thermal energy, kWh & MC & maintenance cost \\
\hline RHF & renewable heat fraction, - & $\mathrm{N}$ & natural gas boiler system \\
\hline RPF & renewable power fraction, - & NP & natural gas \\
\hline SC & storage Capacity, $\mathrm{m}^{3} \mathrm{PVT}^{-1}$ & parasitic & system's parasitic electricity \\
\hline SP & $\begin{array}{l}\text { annual Specific productivity, kWh } \\
\mathrm{PVT}^{-1}\end{array}$ & $\mathrm{~S}$ & $\begin{array}{l}\text { solar assisted ground source } \\
\text { heat pump system }\end{array}$ \\
\hline SPF & seasonal performance factor, - & syn & $\begin{array}{l}\text { synchronized generated and } \\
\text { consumed electricity }\end{array}$ \\
\hline SPPVT_el & $\begin{array}{l}\text { PVT's annual electric specific } \\
\text { productivity, } \mathrm{kWh} \mathrm{PVT}^{-1}\end{array}$ & & \\
\hline $\mathrm{SP}_{\text {sys_heat }}$ & $\begin{array}{l}\text { system's annual heat specific } \\
\text { productivity, kWh PVT }\end{array}$ & & \\
\hline $\mathrm{T}$ & year & & \\
\hline$d$ & Discount rate, \% & & \\
\hline
\end{tabular}




\section{Introduction}

Anthropogenic pollution along with climate change are two of the greatest challenges of our times. Consumption of fossil fuels releases greenhouse gases into the environment and this causes a rise in average global temperature. Part of the solution is to use more renewable energy systems (RES), which can displace conventional energy systems. The RES can be implemented in domestic sector and particularly to provide heat and electricity. Systems like the solar assisted heat pump (SAHP) [1,2] and ground source heat pump (GSHP) $[3,4]$ are two of the promising technologies for reducing carbon emissions. These can be combined as a solar assisted ground source heat pump (SAGSHP) systems $[5,6]$. The first attempt to evaluate SAGSHP systems goes back to the 1970s, with pioneering studies from researchers like Metz [7], since then the interest in this type of systems has grown.

Up to now, the majority of the experimentally [8-11] or theoretically [12-15] investigated SAGSHP systems have been studied with different components, topologies, system-control, and various climates. The type of solar collectors used for the studies of SAGSHP systems range from flat plate collectors (FPC) [16] to PVT collectors [17], while geothermal heat exchangers (GHE) include borehole heat exchangers (BHE) [18] and novel very shallow borefields of some meters deep [11]. These can be paired in numerous combinations, on top of many available system topologies (hydraulic connection of systems) and control strategies [19-23]. It can be concluded that, SAGSHP systems is a complex technology involving many aspects and their design is a site-specific matter, with no established approach.

A very interesting type of SAGSHP system is one equipped with PVT collectors, which can provide both heat and power to the system. Bertram et al. [17] illustrate a PVT-based SAGSHP system with a coaxial BHE installed in Munich. Along with PVTs, a PV panel was installed with the aim to compare the energy generation of the two technologies. By evaluating two years data for the system's operation, the PVT collector was found to produce $4 \%$ more electricity that the PV and the system's seasonal performance factor (SPF) was estimated at 4.2. Another pilot work based on PVT utilization was done by Wright et al. [24], which describes a newly developed house based on zero carbon emission restrictions. The SAGSHP system was equipped with PVTs and a novel very shallow borefield [25]. The GHE was placed underneath the dwelling in order to reduce the heat losses, but there was insufficient monitoring to determine system performance. An experimental SAGSHP system was built by De Montfort University with the aim of evaluating its energy performance for the UK Midlands climate [11]. The system comprised 7 PVT collector and a novel very shallow (1.5 m deep) borefield of 16 BHEs. Based on data collected from June of 2016 until December of 2017 (20 months), the heat pump's SPF was calculated at 2.51.

A simulation-based study was conducted for the Netherlands' climate, with the scope to evaluate the impact of installing PVT collectors in a GSHP system [26]. TRNSYS software [27] was used as simulation platform. The results showed that, $96 \%$ of the system electricity was provided by PVTs, and the $83 \%$ of the heat used by the system was absorbed via the GHE. Another simulation based work with the low exergy concept was carried out with the aim to evaluate the performance of a PVT based SAGSHP system [28]. After modeling the systems in TRNSYS and conducting simulations, the SPF of the system was estimated to be 6.0. A simulation-based evaluation of a SAGSHP system was conducted by C. Emmi et al. [29], with the aim to find out the energetical optimal solution for three European cities. The SAGSHP 
systems was evaluated with flat plate and with PVT collectors, where the use of PVTs seems to benefit the most the performance of the system, by providing both heat and electricity at the same time. A large scale SAGSHP system was evaluated experimentally and theoretically for a village located near by Beijing [30]. With simulations in TRNSYS, the optimum sizes of the borefield and of the hot water tank were estimated. By applying the optimum sizes to the system, the annual COP of the system was increased from 2.42 to 2.65 and a significant reduction in the system's operating cost was estimated.

A multiparametric analysis was made in order to find out the influence of the PVT addition to a GSHP system [31]. In particular, the system was evaluated regarding its energy performance and economy for a multi-family building in Stockholm. The results showed a reduction of 18 $\%$ on the borefield's required length along with $50 \%$ drop on the spacing needed among BHEs. Both achievements have positive financial consequences, and both have been obtained by maintaining an equivalent SPF similar to this achieved by the GSHP system (without PVTs). The decreased system's physical size, contrary to a GSHP system can be translated into reduced initial capital investment. A technoeconomic study was carried out with the aim to determine the benefit of installing FPC on a conventional GSHP system [32]. The research was based on a two-storey building built in Milton (Canada); its energy consumption was monitored thoroughly. A model of the SAGSHP was formulated in TRNSYS and via simulations a parametric analysis was conducted. One of the examined parameters was the ratio between the BHE's length and the collectors' area. The optimum energetically ratio was estimated to be $4.7 \mathrm{~m}$ of BHE per $\mathrm{m}^{2}$ of $\mathrm{FPC}$, and a reduction of $32 \mathrm{~m}$ on the require BHE was estimated if $6.81 \mathrm{~m}^{2}$ of FPC can be installed. The net present value (NPV) index was used to evaluate economically the system for a 20-year period, and through that, the SAGSHP was found with slightly higher present value than the GSHP system.

Ochs et al. [33] conducted an energy and economic analysis for a passive house project in Innsbruck (Austria). The objective was to find the ratio between the PV panels and solar collectors, which is capable to eliminate the consumption of conventional energy sources required for space heating and domestic hot water (DHW). The capitalized cost of the system was used to evaluate economically the results obtained from a 20 -year simulation. The results showed that, the economy of the system was related to the capital cost of the PV system and the unpredictable variation of the electricity price. Finally, the complexity of the system paired with the solar collectors increases and this makes the maintenance cost higher. The life cycle cost (LCC) method was used to assess a SAGSHP systems for Melbourne (Australia) [34]. A simplified model of the system was formulated, and optimization was carried out with the objective to estimate the financially optimum area of solar collector and the volume of the DHW tank. The analysis of the results showed that SAGSHP systems can be a retrofitted solution, while the LCC method was highlighted as the most suitable for energy systems, by including the system's capital and operation costs.

Currently, SAGSHP systems have not been investigated thoroughly from economics perspective, contrary to GSHP or SAHP systems which have received more attention. Two widely implemented methods which can be used to economically assess renewable energy systems for building applications are the LCC [35-40] and the life cycle savings (LCS) method [36]. The LCC method illustrates the present worth of the capital cost along with the sum of the cash flows (CF) over the system's design life. Similarly, the LCS estimates the potential financial savings in present value which can be caused by an investment $[40,43]$.

In this paper, a novel PVT based SAGSHP systems was studied energetically and economically as an energy retrofit solution in a dwelling located in Thessaloniki (Northern Greece). The novelty of the system is based on a very shallow borefield ( $2 \mathrm{~m}$ deep), which potentially may reduce the construction cost of the GHE by avoiding costly deep drilling. A mathematical 
model of the system was formulated in TRNSYS software, with the two of its important components to be experimentally validated. At that time, a simulation based parametric analysis was carried out by varying the number of the PVT collectors and keeping fixed the size of the GHE. The energy assessment of the system was made at a wider point of view by evaluating the results via seven energy metrics, including the newly developed energy index which can be used for systems equipped with PVTs [44] (Renewable Power Fraction, RPF). As for the economic part, the SAGSHP system was compared with a natural gas boiler (NGB) system, as that seems to be a popular solution for space hating and DHW systems. With the need to appraise the economy of the SAGSHP against NGB system, the LCC and the LCS methods were used. The evaluation of the SAGSHP system's economic feasibility is an essential task for the implementation of the proposed technology into the Greek market.

\section{Methodology}

The current study has been conducted for a single-family dwelling located in Thessaloniki, North Greece $\left(40.640^{\circ} \mathrm{N}, 22.806^{\circ} \mathrm{E}\right)$. The weather of the investigated area is characterized as $\mathrm{Csa} / \mathrm{Cfa}$ which means: hot summer Mediterranean climates / humid subtropical, according to the climate classification of the Köppen-Geiger $[45,46]$. The heating degree days for Thessaloniki are 2184 , with the base temperature of $20^{\circ} \mathrm{C}$ [47]. In Figure 1 , the monthly irradiation on a tilted surface $\left(\mathrm{I}_{\mathrm{T}}\right)$ of $30^{\circ}$ south facing and the mean monthly ambient temperature $\left(T_{a}\right)$ are plotted for Thessaloniki.

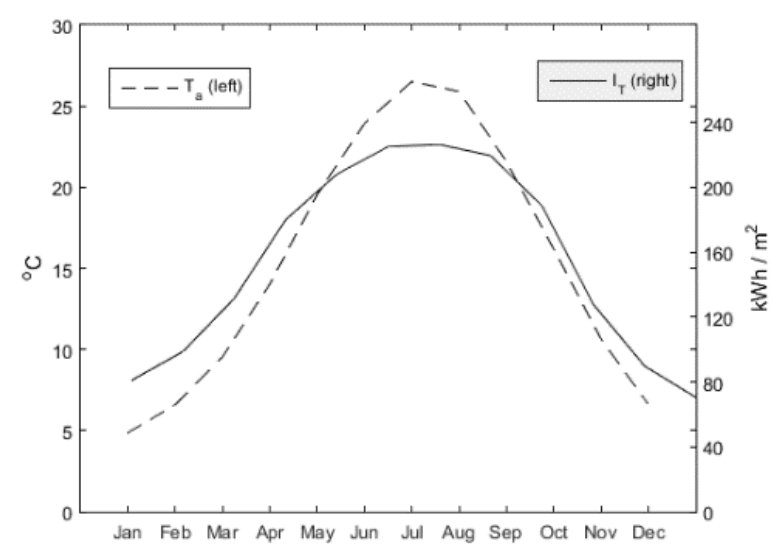

Figure 1. Annual fluctuation of irradiation (line) on the tilted surface $\left(\beta 30^{\circ}, \gamma 0^{\circ}\right)$ and mean ambient temperature (dush line) for Thessaloniki, Greece. (derived from TMY2, Meteonorm)

The SAGSHP system was responsible for providing space heating and domestic hot water (DHW) for the single-family dwelling. The SAGSHP system's main parts were the PVT array, the earth energy bank (EEB) and the heat pump. The analysis of the system along with the dwelling is illustrated in section 2.1, while the topology of the system is shown by Figure 2. A combined model of the SAGSHP system and of the dwelling was formulated in TRNSYS simulation platform [27]. With the developed model, simulation based parametric analysis was conducted by varying the size of the PVT array. Based on that, four simulations were carried out with four different sizes of the PVT array ( 4.8 .12 and 16 collectors).

For the NGB heating system, the natural gas, and the electricity (circulation pump) were the energy sources used for its operation. The system was based on a conventional gas boiler, without heat recovery system (exhaust gas condensation). Hot water was driven at the underfloor space heating system without any additional equipment, like a buffer tank or temperature valve. For the simulation needs, TRNSYS TYPE 700 was used for the boiler, with 
two set point temperatures: one at $31{ }^{\circ} \mathrm{C}$ for the space heating system and the other to be at $50{ }^{\circ} \mathrm{C}$ for DHW. The nominal thermal efficiency of the boiler was set to be $94 \%$ (fixed).

The simulation span was set to be 20 years with one-hour simulation time step. The period of the 20 years is adequate to provide results for both systems by acknowledging that: currently the energy policy across the word is unstable and a longer period may insert inevitable deep uncertainty, and this period is substantial to achieve a monotony regarding the EEB's mean annual temperature, which influences the system's operation. Then with the simulation results, the energy and the economic evaluation of the system was conducted. The energy analysis was made by the metrics which are analyzed in section 2.2 , with the aim to provide information about the performance of the SAGSHP system. As regards the economic assessment, this was conducted by comparing the proposed system with a natural gas boiler system. The economic evaluation was based on the LCC and LCS methods and details about the methodology can be found in section 2.3.

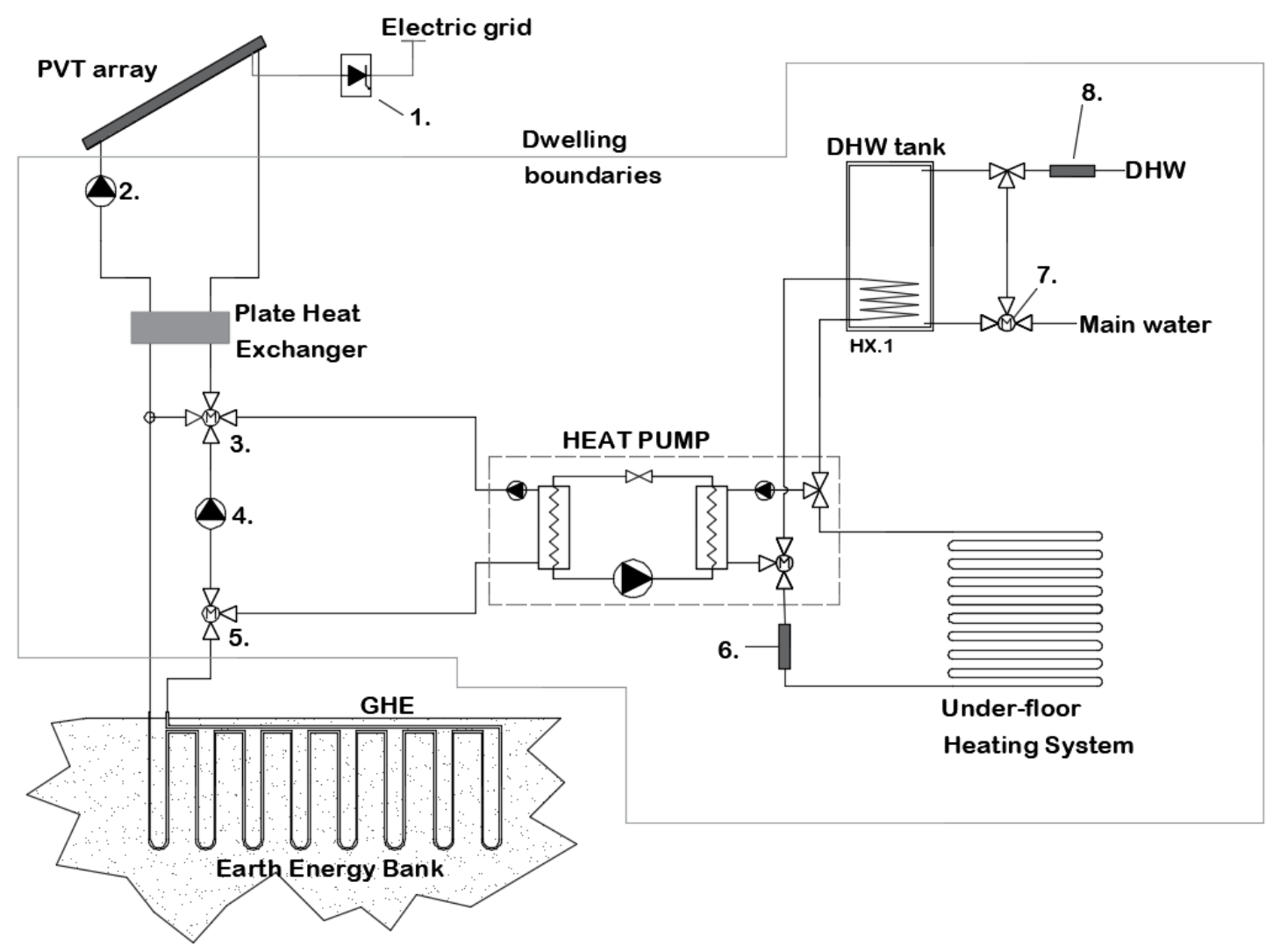

Figure 2. SAGSHP system's layout. 1 DC to AC inverters, 2. Solar system pump, 3. Four-way deviator, 4. Solar-soil charging pump, 5 . Three-way deviator, 6 . Space heating auxiliary heater, 7 . Temperature control valve, 8. DHW auxiliary heater.

\subsection{The energy system and the dwelling}

The analyzed SAGSHP system is based on the experiment which has been conducted by De Montfort University (DMU), information regarding the experiment can be reach in [11][25]. The experimental system with few alterations has been mathematically modeled and formulated in TRNSYS platform [48]. The models of the PVT collectors and of the EEB have previously been validated through experimental data [48]. As the model of the SAGSHP system is already published, the examination of the system is not made in detail and the process is overviewed. More information about the SAGSHP model can be found in [48].

The PVT collectors are connected in series hydraulically with the geothermal heat exchanger (GHE) and the evaporator of the heat pump (Figure 2). The system operates with three modes, 
which are activated via the deviation valves 3 and 5, and the circulation pumps 2 and 4 (Figure 2). The first mode is when there is heating demand and the outlet temperature of the collectors is $6 \mathrm{~K}$ higher than soil's temperature (near boreholes mean temperature), then the solar heat from PVTs was used by the heat pump via the GHE. The second mode is when there is a need for heat, but the outlet temperature of PVTs cannot reach the criterion of $6 \mathrm{~K}$ difference with the soil temperature (due to low irradiance or night and/or high temperature of the soil), then the system operates only with the heat which can be provided by the GHE (by bypassing the PHE). The third operation mode is the case of no heating demand, the solar heat from PVTs (if any) is used to recharge the EEB. As regards the heat pump, this is responsible to provide the under-floor heating system with water at $31^{\circ} \mathrm{C}$ and the immersed heat exchanger in the DHW tank with water at $50^{\circ} \mathrm{C}$. Lastly, the electricity generated by PVTs is injected to the power grid by assuming a total loss of $10 \%$, which counts for cable losses and the efficiency of the inverters. Additionally to the power losses, an annual degradation of $1 \%$ on the electrical efficiency of the PVTs is considered.

As regards the PVT array, this was assumed to be increased from 4 up to 16 collectors, by strings of 4 PVTs connected hydraulically in series (Table 1 ). Thus, the arrays were $4 \times 1,4 \times 2$, $4 \times 3$ and $4 \times 4$ strings by rows, respectively. The PVT arrays are chosen with the aim to offer the economy of the system from a minimum scenario of 4 PVTs, up to a system which can be totally energy self-sufficient and with surplus electricity ( 16 PVTs). For each string of PVTs, a flowrate of $300 \mathrm{~kg} \mathrm{~h}^{-1}$ was applied $\left(75 \mathrm{~kg} \mathrm{~h}^{-1} \mathrm{PVT}^{-1}\right)$ and $8 \mathrm{~m}$ of thermally insulated piping was assumed for every string. A 1D transient model of a retrofitted PVT collector, validated via earlier experimentation, was utilized [49]. The effectiveness of the plate heat exchanger was set to be 0.8 fixed throughout all simulations.

As regards the GHE, it was a very shallow borefield consisting of 16 BHEs of $2 \mathrm{~m}$ vertical length, with distance among the BHEs to be $2 \mathrm{~m}$. The borefield along with the assigned soil mass formed the EEB with a total volume of $110 \mathrm{~m}^{3}$. The borefield was installed exposed, without any thermal insulation and the main parameters of the GHE are listed in Table 1. The studied borefield has been modeled by TYPE 557 from TRNSYS [50] and has been validated via data form DMU's experiment. For the simulation, a new model of the heat pump was developed in TRNSYS simulation platform. The model is partly based on performance data according to EN 14511 and partly on the energy availability on the evaporator's side. Data from a well-known German manufacturer were used. Details about the novel model of the heat pump can be found in [48] and the basic values of the device are listed in Table 1. Finally, electricity was used for auxiliary space heating and DHW when necessary. This is a valid approach for a dwelling size system giving that the electricity is available and the amount of the auxiliary energy is small.

Table 1. Main system parameters.

\begin{tabular}{|c|c|}
\hline Subsystem & Details \\
\hline PVTs & $\begin{array}{l}\text { Four PVT arrays: } 4,8,12 \text { and } 16 \text { collectors. } \\
\text { Peak power } 235 \mathrm{~W}_{\mathrm{p}} \text {. Absorber's area } 1.58 \mathrm{~m}^{2} \text { [49]. } \\
\text { Inclination } 30 \text { degrees, south facing, fixed. }\end{array}$ \\
\hline Borefield & $\begin{array}{l}16 \text { BHEs with very short length of } 2 \mathrm{~m} \text {. } \\
\text { Assigned soil volume } 110 \mathrm{~m}^{3} \text {. } \\
\text { Soil thermal conductivity } 1.5 \mathrm{~W} \mathrm{~m}^{-1} \mathrm{~K}^{-1} \\
\text { Soil heat capacity (clay) } 2400 \mathrm{~kJ} \mathrm{~m}^{-3} \mathrm{~K}^{-1} \\
\text { Distance among BHEs at } 2 \mathrm{~m} \text {. }\end{array}$ \\
\hline Heat pump & $\begin{array}{l}\text { Nominal heat capacity } 4 \mathrm{~kW} \text { TH. }(\mathrm{BO} / \mathrm{W} 50) \\
\text { Nominal power } 1.2 \mathrm{~kW}_{\mathrm{e}} \text {. (BO/W50) } \\
\text { Flowrate evaporator side } 1147 \mathrm{~kg} \mathrm{~h}^{-1} \text {. } \\
\text { Flowrate condenser side } 818 \mathrm{~kg} \mathrm{~h}^{-1} \text {. }\end{array}$ \\
\hline
\end{tabular}




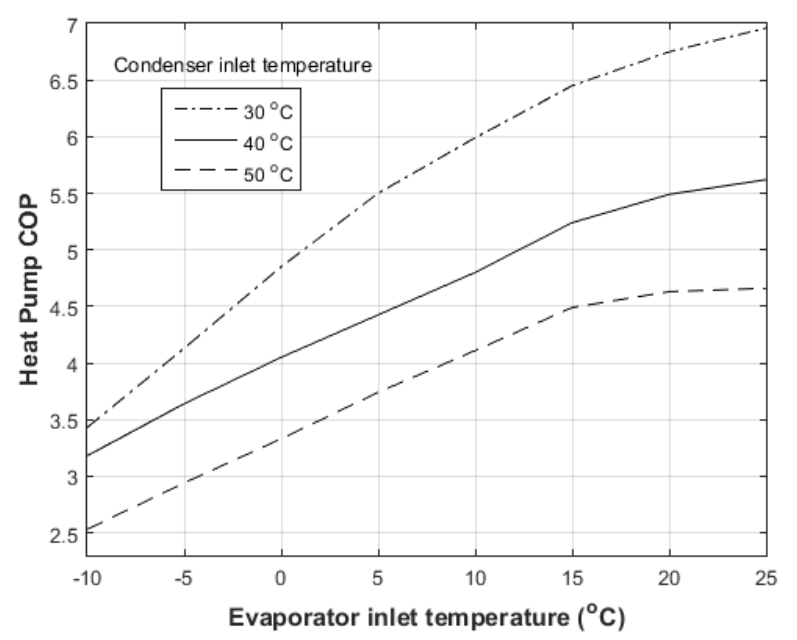

Figure 3. COP of the Heat Pump as function of the evaporator's inle temperature and of the condenser's inlet temperature.

The dwelling modelled was a two-storey building with a total occupation area of $100 \mathrm{~m}^{2}$, for a singly family of four members. This is about the average size of a dwelling [51] for a Greek city suburbs, with the $40 \%$ of these to be occupied by families of 3 to 5 members. It was hypothesized that the dwelling was fully energy retrofitted in accordance with the Technical Chamber of Greece [52] standards for the climate zone of Thessaloniki (third zone, C). The dwelling's model was developed in TRNSYS via TYPE 56 and by adopting all the parameters required by [52] for totally refurbished houses. Also, it was assumed that both storeys were maintained at mean air temperature of $20^{\circ} \mathrm{C}$ all day round. The DHW needs of the dwelling were set to be $50 \mathrm{~L}$ per day per person $\left(200 \mathrm{~L} \mathrm{day}^{-1}\right.$ for a family of four) at $45^{\circ} \mathrm{C}$, in accordance with [52]. The volume of the DHW tank was set to be $260 \mathrm{~L}$ and the consumption profile of DHW was based on the well known f-Chart method [40]. Main parameters of the heating load (space heating and DHW) are listed in Table 2. The space heating load of the system was found to be $9317 \mathrm{kWh}$ per year (93.17 $\mathrm{kWh} \mathrm{m}^{-2}$ per year) and the DHW heating load to be $1243 \mathrm{kWh}$ per year. Roughly, the estimated space heating load of the dwelling is about $17.7 \mathrm{kWh} \mathrm{m}^{-2}$ per year lower than the current average value of dwellings in C climatic zone of Greece, as reported by [53]. With the improved efficiency of the assumed dwelling, the above-mentioned deviation from the average estimated value for $\mathrm{C}$ climatic zone is acceptable.

Table 2. Dwelling's and DHW main parameters values.

\begin{tabular}{|c|c|}
\hline Part & Value \\
\hline Exterior walls U-value & $0.448 \mathrm{~W} \mathrm{~m}^{-2} \mathrm{~K}^{-1}$ \\
\hline Ground floor U-value & $0.706 \mathrm{~W} \mathrm{~m}^{-2} \mathrm{~K}^{-1}$ \\
\hline Exterior roof U-value & $0.406 \mathrm{~W} \mathrm{~m}^{-2} \mathrm{~K}^{-1}$ \\
\hline Windows U-value & $1.272 \mathrm{~W} \mathrm{~m}^{-2} \mathrm{~K}^{-1}$ \\
\hline Windows to walls ratio & $0.15-$ \\
\hline Infiltration & $0.68 \mathrm{ACH}[52]$ \\
\hline Consumption of DHW & $200 \mathrm{~L} \mathrm{day}^{-1}$ at $45^{\circ} \mathrm{C}$ \\
\hline Annual heating load & $9317 \mathrm{kWh}$ at $20^{\circ} \mathrm{C}$ \\
\hline Annual DHW load & $1243 \mathrm{kWh}$ at $45^{\circ} \mathrm{C}$ \\
\hline
\end{tabular}

\subsection{Energy metrics}

Seven energy metrics have been used with the aim to assess the operation of the proposed SAGSHP system for the city of Thessaloniki. The first group of energy performance indexes 
illustrates the fraction of the system's energy consumption provided by renewables. More specifically, in equation 1, the renewable heat fraction (RHF) for the investigated SAGSHP system is shown. The numerator of equation 1 includes: the heat absorbed by the evaporator $\left(Q_{e v}\right)$, the portion of the heat pump's compressor electricity offered with synchronized generation of electricity from PVTs $\left(Q_{H_{-} \text {_syn }}\right)$ and similar the synchronized coverage of the auxiliary heat $\left(Q_{\text {aux_syn }}\right)$. Electric direct heating has been set as the auxiliary heat source. The denominator of equation 1 , holds the heat offered by the condenser $\left(Q_{\text {cond }}\right)$ and the auxiliary heat $\left(Q_{\text {aux }}\right)$ for space heating and DHW.

$$
R H F=\sum_{i=\text { year }}^{20}\left[\frac{Q_{e v}+Q_{H P_{s} s y n}+Q_{a u x_{\_} s y n}}{Q_{\text {cond }}+Q_{a u x}}\right]_{i}
$$

Similarly to the RHF, the renewable power fraction (RPF) [44] illustrates the fraction of the system's electricity covered by the PVTs (equation 2). The RPF is a ratio with numerator the electricity delivered to the power grid by the PVTs (EPVT_u), while the denominator receives all the system's consumption. In more detail, the power consumptions of the system are: the heat pump $\left(E_{H P}\right)$, the consumption on the circulation pumps ( $\left.E_{\text {parasitic }}\right)$ and the auxiliary heat $\left(E_{\text {aux }}\right)$. In our case the $Q_{\text {aux }}$ and the $E_{\text {aux }}$, represent the same amount of energy.

$$
R P F=\sum_{i=\text { year }}^{20}\left[\frac{E_{P V T \_u}}{E_{H P}+E_{\text {parasitic }}+E_{\text {aux }}}\right]_{i}
$$

In accordance with the European Union's classification for the seasonal performance factors (SPF) of the heat pump systems [54], the one specified by the fourth boundary was utilized $\left(\mathrm{SPF}_{\mathrm{H}}\right)$. The $\mathrm{SPF}_{4}$ states the ratio between the delivered heat by the system and the system's electricity balance (consumption - generation). Based on that concept, two scenarios were investigated: the electricity generated by PVTs to be included on the denominator of equation 3 (consolidated SPF), the second scenario is to exclude the EPVT_u from equation 3 (nonconsolidated SPF*).

$$
S P F=\frac{\sum_{i=\text { year }}^{20}\left(Q_{\text {cond }}\right)_{i}}{\sum_{i=\text { year }}^{20}\left(E_{H P}+E_{\text {parasitic }}+E_{\text {aux }}-E_{P V T_{-} u}\right)_{i}}
$$

The last set of indexes is about the annual specific productivity (SP) of the system and of the PVT collectors. In general, the SP indices illustrate the energy production per installed PVT collector. It is worth reminting, that the borefield was kept fixed throughout simulations, thus only the PVTs were the energy harvesting equipment which was varying. With equation 4 , the system's heat SP (SP sys_heat $_{\text {) }}$ can be calculated. The system heat SP considers the evaporator of the heat pump as the boundary in which the system received its heat [48].

$$
S P_{\text {sys_heat }}=\frac{\sum_{i=\text { year }}^{20}\left(Q_{e v}\right)_{i}}{n_{P V T} \cdot 20_{\text {years }}}
$$


In the same way as with the $\mathrm{SP}_{\text {sys_heat, }}$ the PVT's heat and electric SP can be calculated via equation 5 and equation 6 accordingly. The PVT's heat SP (SPPV_ heat), calculates the annual heat production per collector and the PVT's electric SP (SPPVT_el) computes the annual yield per PVT.

$$
\begin{aligned}
& S P_{P V T_{-} \text {heat }}=\frac{\sum_{i=\text { year }}^{20} Q_{P V T_{-} \text {heat }}}{n_{P V T} \cdot 20_{\text {years }}} \\
& S P_{P V T_{-} \text {el }}=\frac{\sum_{i=\text { year }}^{20} E_{P V T_{-} i}}{n_{P V T} \cdot 20_{\text {years }}}
\end{aligned}
$$

\subsection{Economic analysis}

The objective of the conducted economic analysis was to compare the proposed SAGSHP system with the NGB system for the city of Thessaloniki. Both systems had the same aim, which was to fulfill the annual space heating and DHW needs of the dwelling (section 2.1). The economic comparison of the systems was made via the LCS and the LCC method. The LCS is the difference between the LCC of the NGB $\left(\right.$ LLC $\left._{N}\right)$ and LCC of the SAGSHP ( LCC $\left._{S}\right)$ system $[40,43]$. It is to be clarified that, the LCS can be annotated as NPV [40], and in the present work, the NPV is used to illustrate the difference between the LCCs of the two systems (equation 11). Thus, the NPV illustrates the life cycle savings (in present worth) achieved by the SAGSHP system against the NGB system over the period of the 20 years. Based on the above method, the SAGSHP system is cost effective for positive values of NPV. Also, in this study none probabilistic method is used, thus no elements of randomness are considered.

The LCC method estimates the present worth of the system's total cost, by considering the energy cost, maintenance and replacements, the capital cost, and the potential income from the electricity of PVTs. Thus, the system with lower LCC is the most cost effective, in contrast to the LCS method in which a positive NPV depicts the cost effectiveness of the system.

With the aim to calculate the LCC of the systems, the present worth of the annual cash flow $\left(C_{T}\right)$ was estimated, for every simulation year $(T)$. For the SAGSHP system the $\mathrm{CF}_{S_{-} T}$ was estimated with equation 7 and for the NGB system the $\mathrm{CF}_{\mathrm{N}_{-} \mathrm{T}}$ was estimated via equation 8 . The LCC in both cases was estimated by discounting and summing the twenty cash flows by using equation 9. It was assumed that, both systems were financed via a bank loan. As regards the periodic payment (PP) of the bank loan for both system, this was estimated in accordance with equation 10.

$$
\begin{aligned}
& C F_{S_{-} T}=\left[E_{\text {used } \_} \cdot\left(E P \cdot\left(1+i_{E P}\right)^{T-1}\right)\right]-\left[E_{P V T_{-} u} \cdot\left(F I T \cdot\left(1+i_{F I T}\right)^{T-1}\right)\right] \\
& +P P_{S_{-} T}+M C_{S} \cdot\left(1+i_{M C}\right)^{T-1} \\
& C F_{N_{-} T}=\left[Q_{u s e d} \cdot\left(N P \cdot\left(1+i_{N P}\right)^{T-1}\right)\right]+\left[E_{\text {used } N} \cdot\left(E P \cdot\left(1+i_{E P}\right)^{T-1}\right)\right] \\
& +P P_{N_{-} T}+M C_{N} \cdot\left(1+i_{M C}\right)^{T-1}
\end{aligned}
$$




$$
\begin{gathered}
L C C=\sum_{T=1}^{T=20} \frac{C F}{(1+d)^{T}} \\
P P=C C \cdot\left(i_{B i}+\frac{i_{B i}}{\left(1+i_{B i}\right)^{Y}-1}\right) \\
N P V_{(L C S)}=L C C_{N}-L C C_{S}
\end{gathered}
$$

Table 3 illustrates all the parameters used for the economic evaluation of the systems and in Table 4, the capital cost of the systems is break down. The initial cost of the SAGSHP system was varying in accordance with the number of the PVT collectors, thus four capital costs were estimated. Also, along with the annual fixed expenses for maintenance, some additional costs for replacements were considered (Table 3). These expenses for the SAGSHP system were the change of the photovoltaic inverter in the $12^{\text {th }}$ year $(1000 €)$ and a major repair for the heat pump in $18^{\text {th }}$ year $(2000 €)$. Regarding the NGB system the only additional repair cost was the boiler's replacement in $12^{\text {th }}$ year $(1200 €)$. The initial cost of the two systems, SAGSHP and $\mathrm{NGB}$, and the maintenance costs have been appraised after consultation with the industry. Lastly, the resale value for both systems is excluded from the evaluation.

As the base case, PVTs were connected to power grid via a net metering scheme. This method applies a net balance between the imported and exported electricity. But, equation 7 is written by applying a feed-in-tariff (FIT) to the energy injected from PVTs to the power grid. In the base case, the FIT was set to be equal to the domestic electricity price (net metering). However, it is important to evaluate the influence of the FIT price on the system's economic

\begin{tabular}{|c|c|}
\hline Parameter & Value \\
\hline Domestic electricity price [EP] & $0.16 € k W h^{-1}$ \\
\hline Natural gas price [NP] & $0.06 € k W h^{-1}$ \\
\hline Domestic electricity inflation rate [i $\left.\mathrm{i}_{\mathrm{EP}}\right]$ & $2 \%$ \\
\hline Natural gas inflation rate [i $\left.\mathrm{i}_{\mathrm{NP}}\right]$ & $2 \%$ \\
\hline $\begin{array}{l}\text { Annual maintenance cost of the } \\
\text { SAGSHP system }\left[\mathrm{MC}_{\mathrm{S}}\right]\end{array}$ & $100 €$ \\
\hline $\begin{array}{l}\text { Annual maintenance cost of the NGB } \\
\text { system }\left[\mathrm{MC}_{\mathrm{N}}\right]\end{array}$ & $70 €$ \\
\hline Maintenance const inflation rate $\left[\mathrm{i}_{\mathrm{MC}}\right]$ & $3 \%$ \\
\hline Discount rate [d] & $3 \%$ \\
\hline Bank load interest rate $\left[\mathrm{i}_{\mathrm{B} i}\right]$ & $9 \%$ \\
\hline Bank loan period [Y] & 5 years \\
\hline Period of the economic analysis & 20 years \\
\hline
\end{tabular}
viability, thus the equation 7 assumes a FIT scheme.

Table 3. Parameters used for the economic analysis.

\begin{tabular}{|c|c|c|c|c|c|}
\hline \multirow[b]{2}{*}{ Part } & \multicolumn{4}{|c|}{ SAGSHP } & \multirow[b]{2}{*}{ NGB $[€]$} \\
\hline & $\begin{array}{l}4 \text { PVT [€] } \\
940 W_{p}\end{array}$ & $\begin{array}{l}8 \text { PVT [€] } \\
1880 W_{p}\end{array}$ & $\begin{array}{c}12 \text { PVT [€] } \\
2820 W_{p}\end{array}$ & $\begin{array}{c}16 \text { PVT [€] } \\
3760 W_{p}\end{array}$ & \\
\hline Solar system & 1191 & 2682 & 4173 & 5664 & - \\
\hline
\end{tabular}

Table 4. Breakdown of the initial investment costs of the four SAGSHP scenarios and the alternative NGB system. * Instalation costs for SAGSHP systems are included in the cost of each subsysem-part. 


\begin{tabular}{|l|c|c|c|c|c|}
\hline Heat pump & 5500 & 5500 & 5500 & 5500 & - \\
\hline EEB & 2000 & 2000 & 2000 & 2000 & - \\
\hline NGB & - & - & - & - & 1300 \\
\hline Installation & $*$ & $*$ & $*$ & $*$ & 1200 \\
\hline Capital cost & 8691 & 10182 & 11673 & 13164 & 2500 \\
\hline
\end{tabular}

Along with the LCC and LCS methods, the annualized cost of heat (ACOH) was calculated for both systems (equation 12). The $\mathrm{ACOH}$ can be used to determine the cost effectiveness of a system and to calculate the annualized cost per unit of heating load $\left(€ \mathrm{kWh}^{-1}\right)$. Although the $\mathrm{LCC}$ and the $\mathrm{ACOH}$ are capable to indicate which system is more economic, the $\mathrm{ACOH}$ index offers a value which can be used for comparison with another type of system, for future works.

$$
A C O H=\frac{L C C}{\frac{1}{d}\left[1-\left(\frac{1}{1+d}\right)^{20}\right] \cdot L}
$$

\section{Results and discussion}

\subsection{Energy evaluation}

Figure 4 show the RHF and the RPF for all PVT array scenarios. As it can be observed, the heat independence of the system increase as the PVT array enlarges. The lower RHF is calculated at 0.59 for the PVT array of 4 collectors and with the addition of 4 more PVTs the RHF increments to 0.66 . For the arrays of 12 and 16 PVT collectors, the RHF rises by the fraction of 0.04 and 0.07 from the array of 8 collectors, respectively. As it can be seen, the influence of the PVTs on the RHF decreases as the array enlarges. The reason behind this phenomenon is the soil temperature in the EEB, which is function of the number of PVTs. As it can be seen in Figure 5, the larger the PVT array the higher the mean soil temperature in the EEB. With higher soil temperature, the circumstances of obtaining a $\Delta T$ of $6 \mathrm{~K}$ (differential thermostat) between the outlet of the PVTs and the soil near boreholes are less. Therefore, the ability of the solar system to provide heat is regulated by the level of the mean soil temperature.

By breaking the RHF down for all scenarios (Table 5), the larger part was offered via the evaporator of the heat pump $\mathrm{RHF}_{\mathrm{ev}}\left(\mathrm{Q}_{\mathrm{ev}}\right.$, equation 1 ), while a smaller amount was inserted by the synchronized operation of the heat pump with the PVTs' power generation $\mathrm{RHF}_{\mathrm{HP}_{\mathrm{B}} \text { syn }}$ ( $Q_{H P_{-} \text {syn, }}$ equation 1). Also, the portion of heat which was entered to the system by the synchronized operation increases as the PVT array enlarges (Table 5). This was caused by the higher capacity of larger PVT arrays to provide more electricity. 


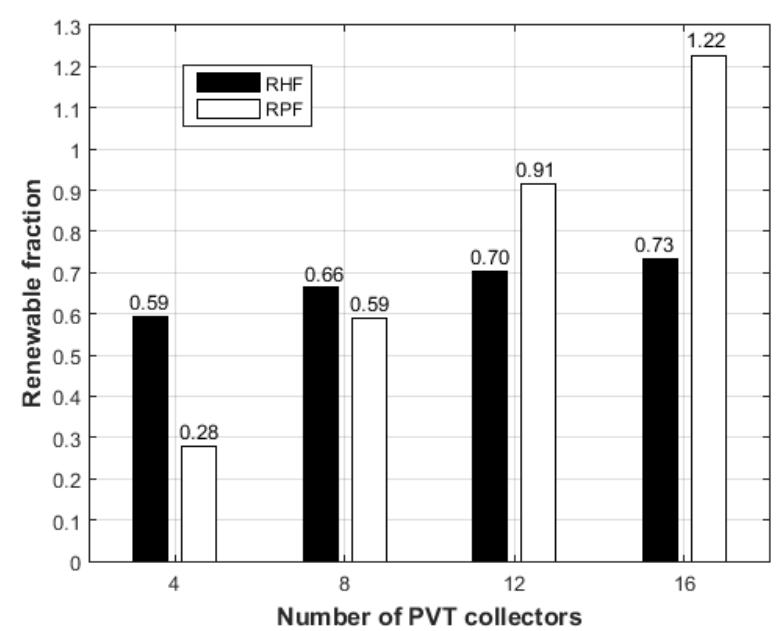

Figure 4. RHF and RPF for all PVT array scenarios.

Figure 4 shows that RPF increases linearly as the PVT array enlarges, from 0.28 to 1.22 for the array of 4 and 16 PVTs respectively. Only the largest system with the 16 collectors can provide more electricity than this used by the system (RPF $>1$ ). The increase in number of PVTs influences the system's RPF in two ways: firstly, more PVTs increase the electricity generated by the system and secondly, the larger PVT arrays increase the mean soil temperature (Figure $5)$, which improves the performance of the heat pump and consequently reduces the electricity used on the heat pump and as auxiliary ( $E_{\text {aux }}$ ) (Figure 6). The reduction of the electricity consumed by the heat pump was made by the evaporator's increased inlet temperature, which was caused by the higher soil temperature. Similarly, the higher mean soil temperature can offer to the system a greater heat sufficiency and by that the $E_{\text {aux }}$ can be reduced. As regards the parasitic electricity ( $\left.E_{\text {paracitic }}\right)$ in Figure 6 , as the PVT array enlarges the consumption increases due to the larger facility of the system.

Table 5. Break down of the RHF for all PVT arrays. Where the $\mathrm{RHF}_{\mathrm{ev}}$ and RHF $\mathrm{RP}_{-}$syn have been calculated by placing on the numerator of equation 1 only the $\mathrm{RHF}_{\mathrm{ev}}$ and $\mathrm{RHF}_{\mathrm{HP} \_ \text {syn }}$ respectivelly.

\begin{tabular}{|c|c|c|c|}
\hline $\begin{array}{c}\text { PVT } \\
\text { array }\end{array}$ & RHF $_{\text {ev }}$ & RHF $_{\text {HP_syn }}$ & RHF \\
\hline 4 & 0.56 & 0.03 & 0.59 \\
\hline 8 & 0.61 & 0.05 & 0.66 \\
\hline 12 & 0.64 & 0.06 & 0.70 \\
\hline 16 & 0.66 & 0.07 & 0.73 \\
\hline
\end{tabular}




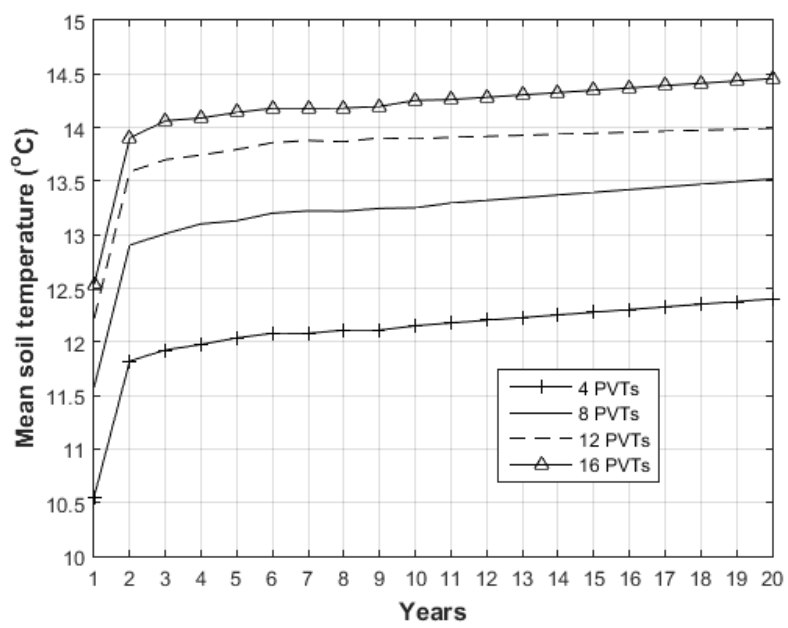

Figure 5. Mean soil temperature of the EEB for all PVT array scenarios.

In Table 6, the consolidated (SPF) and the non-consolidated (SPF*) seasonal performance factors are listed for all PVT arrays (section 2.2). By considering the electricity generated by PVTs on the SPF calculations, the SPF was found between 3.14 and infinity for the arrays of 4 PVTs and 16 PVTs respectively. The infinity value of the SPF with the array of 16 collectors was achieved by generated more electricity than the system's consumption. This is visualized in Figure 4, where the RPF is illustrated to be 1.22 times greater than the consumption. As regards the SPF*, the lower value was calculated to be 2.27 with 4 PVTs and increases up to 2.74 as the array enlarges. It is worth noting, that the increase of the SPF* as the PVT array enlarges was caused by the grown of $Q_{e v}$ and $Q_{\text {syn }}$ (Table 5 ), and by the system's reduced electric consumption (Figure 6). Finally, the smaller PVT arrays contribute more on the increase of the SPF* (from 4 to 8 PVTs), however with larger PVT arrays the contribution declines. This pattern is similar to this identified for the relation between the $Q_{e v}$ and the mean soil temperature of the EEB. With larger arrays, the soil of the EEB becomes warmer, and this constrains the absorption of the solar heat by the system.

Table 6. Consolidated (SPF) and non-consolidated (SPF*) for all PVT arrays.

\begin{tabular}{|c|c|c|}
\hline $\begin{array}{c}\text { PVT } \\
\text { array }\end{array}$ & SPF & SPF* \\
\hline 4 & 3.14 & 2.27 \\
\hline 8 & 6.14 & 2.53 \\
\hline 12 & 31.25 & 2.67 \\
\hline 16 & $\infty$ & 2.74 \\
\hline
\end{tabular}




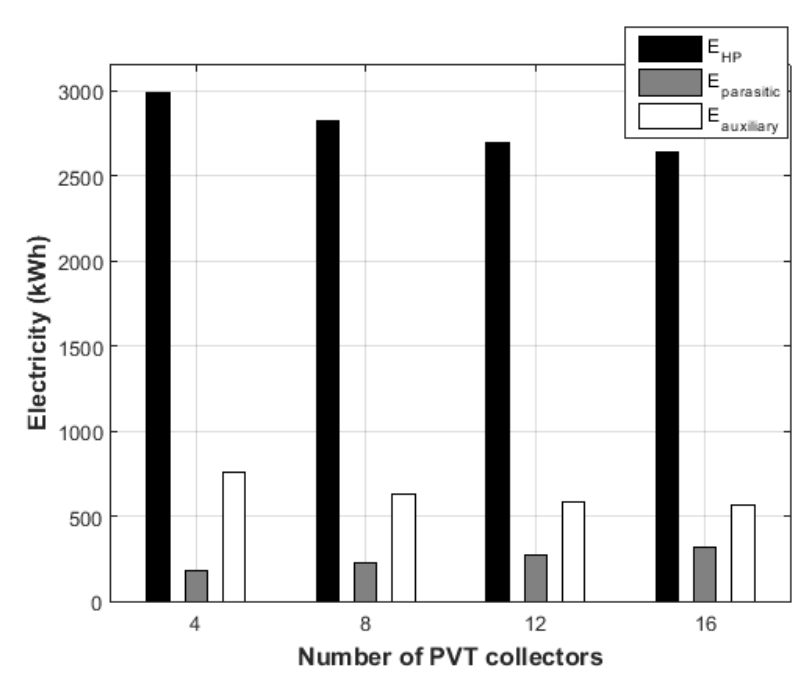

Figure 6. Mixture of the electricity used by the system all PVT array scenarios. (it is assumed that the auxiliary heat is provided via electricity).

The estimated specific productivities (SP) of the PVTs and of the system are listed in Table 7. The higher electric and heat SP of the PVTs was achieved with the array of 4 PVT collectors. The SP PVT_el $_{\text {Was estimated from } 301.5 \text { to } 300.9 \mathrm{kWh} \mathrm{PVT}^{-1} \text { and the SPPVT_heat }}$ from 1213.1 to $1114.7 \mathrm{kWh} \mathrm{PVT}^{-1}$, in both cases with the array of 4 and 16 PVTs respectively. Regarding the electric SP of the PVTs, this was found to reduce as the collector array enlarges, because of the increased mean soil temperature of the EEB (Figure 5). With an elevated soil temperature, a higher PVTs inlet temperature was obtained and the operation of the circulation pump of the solar system $(\Delta T 6 \mathrm{~K})$ was constrained. Both consequences of the higher soil temperature increase the temperature of the photovoltaic cells and by that to reduce their electrical efficiency, although only very slightly. The PVTs' heat SP was found to drop as the array enlarges through the same mechanisms mentioned above for the SPPVT_el. A drop on the PVT thermal efficiency was produced by their elevated inlet temperature.

The system's heat SP was found to drop exponentially as the PVT array grows. For the array of 4 PVTs, the SP sys_heat was estimated to be $1483.3 \mathrm{kWh} \mathrm{PVT}^{-1}$, which is $270.2 \mathrm{kWh} \mathrm{PVT}^{-1}$ higher than the solar heat per collector offered by PVTs (Table 7). In contrast, for the larger array of 16 PVTs, the system's heat SP was estimated to be $438.9 \mathrm{kWh} \mathrm{PVT}^{-1}$, which is $675.8 \mathrm{kWh} \mathrm{PVT}^{-}$ ${ }^{1}$ lower than the SP offered by the PVTs. The main reason which constrains the $\mathrm{SP}_{\text {sys_heat }}$ is the fixed annual heating demand of the dwelling, that imposes a ceiling where beyond that evaporator cannot absorb heat. This means that with a higher heating load (larger dwelling or less well insulated), the heat SP of the system can be increased.

Table 7. Electric and heat specific productivity of the PVTs and system for all PVT arrays.

\begin{tabular}{|c|c|c|c|}
\hline PVTs & $\begin{array}{c}\text { SPPV_el } \\
{\left[\mathrm{kWh} \mathrm{PVT}^{-1}\right]}\end{array}$ & $\begin{array}{c}\text { SPPVT_heat } \\
{\left[\mathrm{kWh} \mathrm{PVT}^{-1}\right]}\end{array}$ & $\begin{array}{c}\mathrm{SP}_{\text {sys_heat }} \\
{\left[\mathrm{kWh} \mathrm{PVT}^{-1}\right]}\end{array}$ \\
\hline 4 & 301.5 & 1213.1 & 1483.3 \\
\hline 8 & 300.8 & 1167.3 & 809.4 \\
\hline 12 & 300.2 & 1134.4 & 565.3 \\
\hline 16 & 300.9 & 1114.7 & 438.9 \\
\hline
\end{tabular}

As it can be seen in Figure 7, the solar system is capable of delivering heat $\left(Q_{\text {sol }}\right)$ all year round on the EEB. The maximum values of the $\mathrm{Q}_{\text {sol }}$ were estimated for the period between April and July, while the lower value was found on October. After summer, the EEB has reach the maximum level of heat storage which can obtain with the given PVT array (stagnated). Thus, 
the $\mathrm{Q}_{\text {sol }}$ was declined until October, by following the GHE heat flow $\left(\mathrm{Q}_{\mathrm{GHE}}\right)$. From April to September the solar heat is partially stored in the EEB and partial used directly by the heat pump. Thus, after the October, the $Q_{G H E}$ turns to negative values by absorbing the heat from the EEB. Note that the heat sources of the EEB are the solar heat and the heat gains (or losses) entering to/from the surrounding soil masses. The heat entering to the EEB bank from the adjacent soil mass is part of the natural recovery mechanism. Therefore, from March until May, the variation of the internal heat of the EEB $\left(\Delta Q_{\text {EEB_int }}\right)$ is higher than the solar heat offered via the GHE. The amount of heat which is needed to balance the $\Delta \mathrm{Q}_{\text {EEB_int }}$ with the $\mathrm{Q}_{\text {GHE }}$ was offered by the adjacent soil, which was at a higher temperature than the EEB. It can be concluded, that the heat sources of the system are solar energy and the shallow geothermal energy.

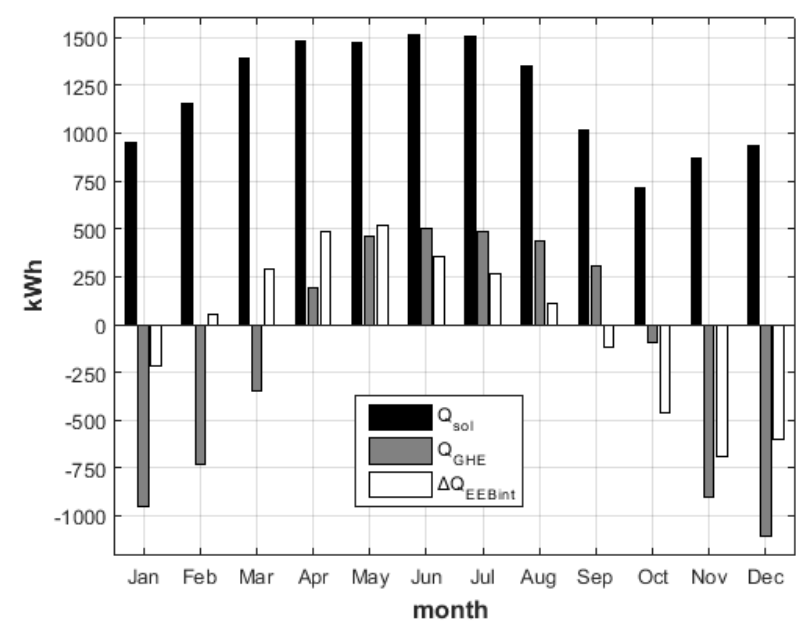

Figure 7. Year-round solar heat delivered to the EEB $\left(\mathrm{Q}_{\text {sol }}\right)$, the heat flow of the GHE and the variation of the internal heat of the EEB, for the array of 12 PVTs in the $10^{\text {th }}$ year of simulation.

\subsection{Economic evaluation}

Figure 8 illustrates the LCC values of the four PVT scenarios along with the LCC $_{N}$. The estimated $L C C_{S}$ and $L C C_{N}$ have been calculated via the base case values listed in Table 3 and Table 4, with all the parameters used remaining fixed. As it can be seen in Figure 8, the LCC of the SAGSHP systems drops as the PVT array enlarges. In details, the LCC of the system with the 4 PVTs was estimated to be $22703 €$ and declines linearly at $17787 €$ for the largest array of 16 collectors. Only the system with 16 PVTs was found with low LCC than the $L_{C C}$, while the system with 12 PVTs was estimated with slightly negative NPV (NPV $\left.=L_{C C}-L_{N} C_{S}\right)$. Although the larger PVT arrays have higher capital cost (Table 4), the ability to reduce the imported electricity was found to be the key factor for its financial viability. Also, the surplus energy produced by the array of 16 PVTs can be used for dwelling's appliances (like lights and washer). The imported electricity was diminished by improving the performance of the heat pump, the elimination of the auxiliary heat and the grow of the generated electricity by PVTs. Finally, the present economic analysis does not include the impact of the pollution by the conventional NGB. However, when pollution control is the primary concern, the economics of such systems would be better. 


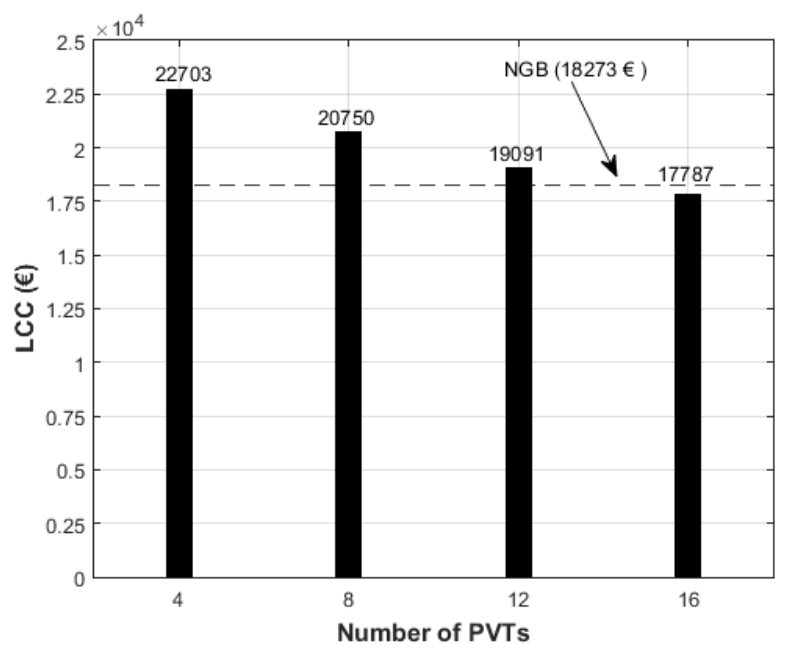

Figure 8. LCC of the four system scenarios against the NGB system (dashed line), produced with the values of the parameters listed in Table 3.

With Figure 9 and Figure 10, the NPV (equation 11) for the scenarios with 4 and 12 PVTs is illustrated respectively, as function of four important economic parameters: the capital cost (CC), the discount rate (d), the electricity price (EP) and the natural gas price (NP). In Figure 9 and Figure 10, the horizontal line at zero NPV divides the chart into the upper region, where the system is economic and to the one below where it is uneconomic. For the system with the array of 4 collectors (Figure 9), all parameters were found affect the NPV significantly. The reduction of the system's capital cost and the price of electricity were found to increase the NPV. In contrast, the increase of the natural gas price and discount rate was estimated to raise the NPV. The system's economic viability was affected by the low RPF (28\%) (Figure 4), the remaining portion of electricity was imported. In Figure 9, the appraised capital cost of the SAGSHP system was set to vary from $-60 \%$ to $40 \%$, by taking to the account any under or over appraisal of the investment's initial cost. Nevertheless, the system with 4 PVTs was managed to be better monetary investment than the NGB system with about $44 \%$ reduction on the capital cost. Alternatively, the SAGSHP system of 4 PVTs can be more economic than the NGB system by a raise on price of the natural gas by $38 \%$. Throughout the variation of the discount rate $(-60 \%$ to $100 \%)$ and the given base case parameters of the analysis (Table 3 ), the SAGSHP system with 4 PVTs cannot be a viable monetary solution. Lastly, as regards the electricity price, there is a need for a generous reduction of $62 \%$ on the price in order the SAGSHP system to be viable against the NGB system. 


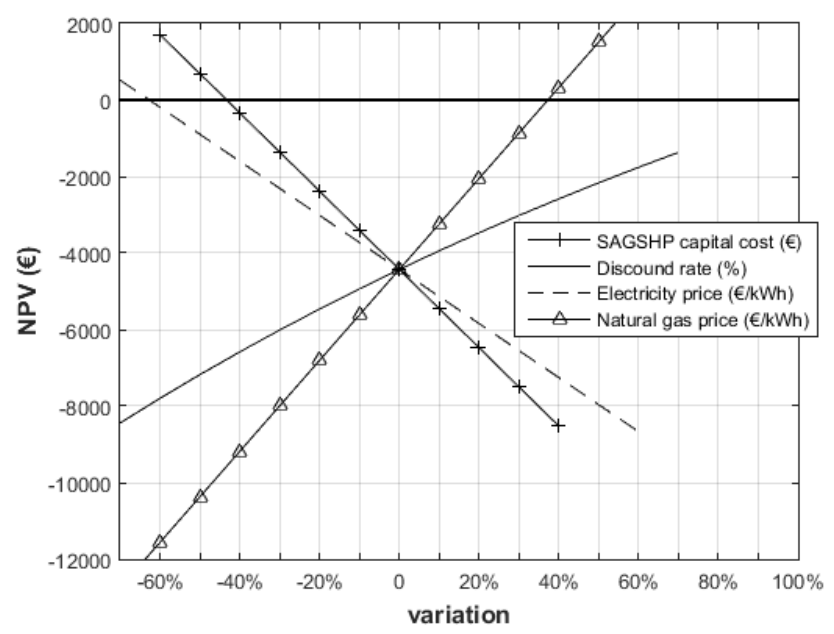

Figure 9. Estimated NPV of the SAGSHP system with 4 PVTs as function of the capital cost, discount rate, electricity price and natural gas price.

The SAGSHP system with the array of 12 PVTs has initial investment cost about $3000 €$ higher than the system with 4 PVTs (Table 4), but its RPF is increased by 0.63 (Figure 4). As it can be seen in Figure 10, the price of electricity does not influence the NPV due to the higher RPF (0.91) which reduces the imported electricity. By limiting the need for imported electricity, the capital cost of the system and the price of natural gas were found to affect significantly the NPV. In detail, the SAGSHP system with 12 collectors can be a better monetary solution than the NGB system by reducing slightly its capital cost $(-7 \%)$, the point at which the SAGSHP line crosses the $x$-axis in Figure 10. Similarly, the price of the natural gas influences significantly the economic viability of the system. A rise of the natural gas price of $8 \%$ makes the SAGSHP system the same cost as the NGB system. Finally, the NPV becomes positive by increasing the discount rate by $26 \%$ of the reference value, from $3 \%$ to $3.78 \%$.

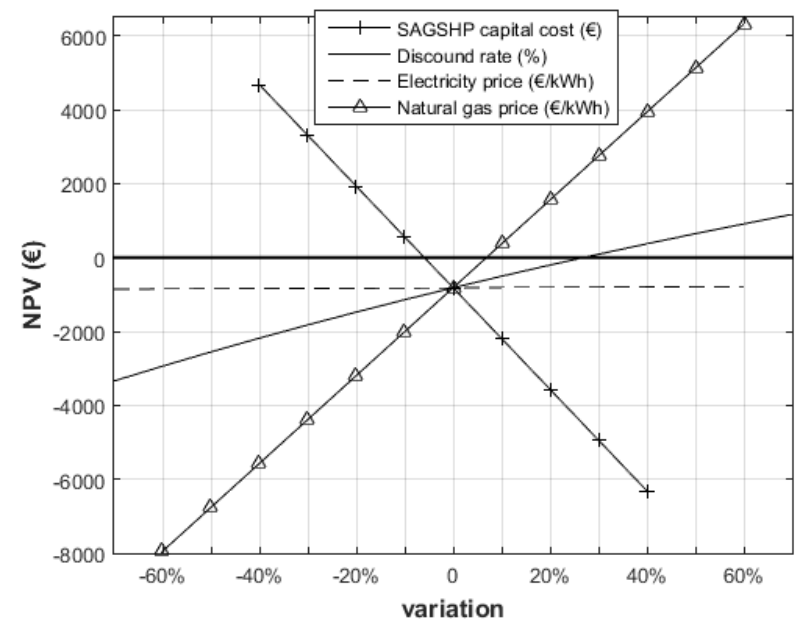

Figure 10. Estimated NPV of the SAGSHP system with 12 PVTs as function of the capital cost, discount rate, electricity price and natural gas price.

An important parameter for the SAGSHP system financial evaluation is the applied discount rate, which implicitly indicates the anticipated economical gain of the investment. Figure 11, shows the correlation between the NPV for all PVT arrays with the discount rate's variation from $0 \%$ up to $12 \%$ (all other parameters remain fixed). The utilized range of the discount rate is wide enough to include the most commonly used discount rates. It should be noted that the variation of the discount rate is applied only on the SAGSHP system. Based on the results, all 
system appears to be cost effective under an increase in the chosen discount rate. The NPV turns to positive with discount rate between $2.4 \%$ and $6.2 \%$, for the PVT array of 16 and 4 collectors, respectively. Also, the systems with 12 and 8 PVTs require discount rates of 3.75 and $5 \%$ respectively in order to become monetary viable. The increase of the NPV as the discount rate grows (Figure 11), lies in the ability of higher discount rate to require lower LCCS and consequently the difference between the $L C C_{N}$ increases (NPV $=L_{C C} C^{-} L C C_{S}$ ).

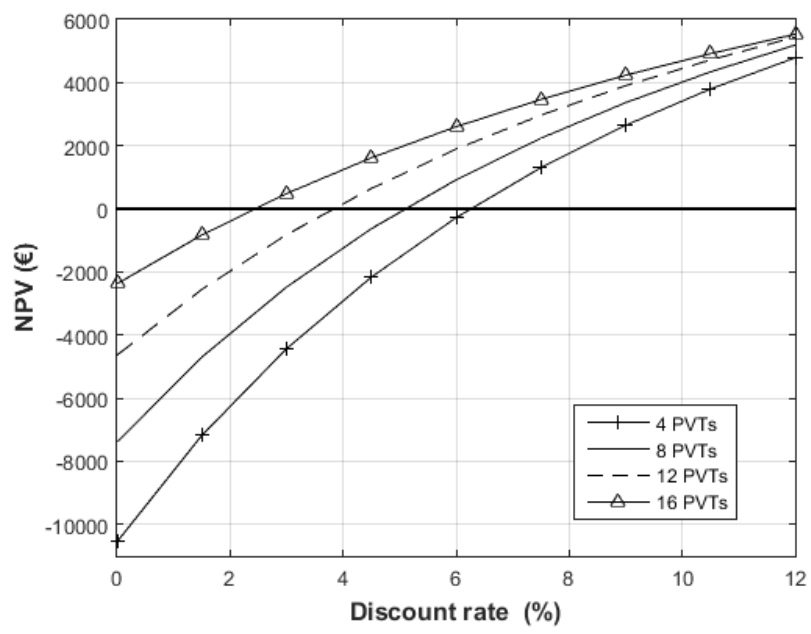

Figure 11. NPV of the SAGSHP system for its four PVT arrays as function of the discount rate.

Giving that economic viability of the SAGSHP system is under investigation at the current state, the government may offer some benefits, in favor of the wider implementation of this type of systems. With the incentive to reduce the carbon-dioxide emissions and the reduction of the conventional energy sources consumption, local governances should invest in renewable energy systems. Thus, with the aim to make the SAGSHP system an attractive financial choice, favorable measures should be established. These actions can be: to subsidize a portion of the capital cost of the system, to establish a feed-in-tariff (FIT) scheme for the generated electricity by PVTs, and to create favorable conditions regarding the payment of the investment loan.

Figure 12 shows how the subsidized initial cost of the investment influences the NPV, for all four PVT schemes. As it can be seen, by excepting the system with the 16 PVTs which is viable without subsidy, all other three SAGSHP system configurations can be financially viable with a portion of the initial cost to be offered by the government. In details, the system with the 12 PVT can be economic with less than $10 \%$ support, while for systems with 8 and 4 PVTs, the government should cover the $20 \%$ and slightly more than $40 \%$ of the capital cost respectively. The subsidy of the system's capital cost can be directly by reducing the VAT and/or to fund a portion, or implicitly via the tax credit of the owner. It is worth mentioning, that currently the VAT in Greece is $24 \%$, and by accepting a zero VAT purchase, a reduction of $19 \%$ of the system capital cost can be accomplished. 


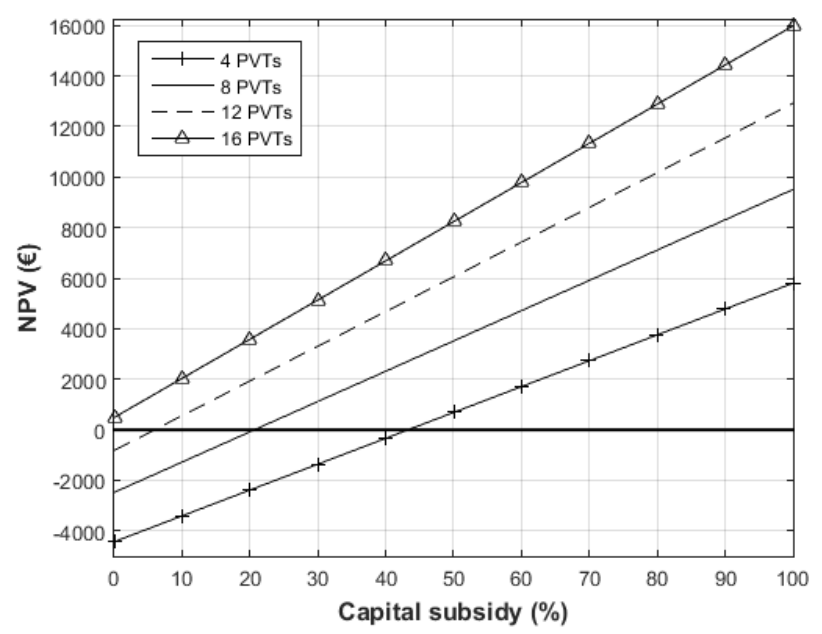

Figure 12. NPV achieved by the investigated PVT arrays as function of the portion of the capital subsidy.

Figure 13 illustrates the NPV of the systems as function of the FIT prices. The variation of the FIT price was set to be from 16 (the assumed import price and base case FIT value) up to 32 cents of euro per kWh, which is a conservative fluctuation giving that FITs in Greece used to be as high as 55 cents of euro per $\mathrm{kWh}$. It is pertinent to remind that FIT schemes require two power meters, one for the imported electricity and one for the exported. The balance between the inlet and outlet values of energy is made financially. As it is illustrated in Figure 13 , the system with 4 PVT is uneconomic for all listed values of FIT and the conventional NGB is the economic choice. As regards the systems of 8 and 12 PVTs can be an efficient monetary solution against the NGB system with FITs higher than 17 and 23 cents of euro per kWh respectively. It seems, that even a small revenue made from the slightly increased FIT is capable to establish the system with 12 PVT an economic solution. Finally, the system with the 16 collectors appears to be a superior economic solution compared to the conventional NGB. The larger PVT arrays are benefited the most as the FIT increments, due to their higher electricity generation, which can exceed the cost of the consumption. Nevertheless, in the case of increasing the FIT price on the systems with the 12 and 16 PVTs, the system owner can have an annual income from the generated electricity, on top of the totally covered heating needs. Lastly, based on the experience from other countries like the UK, the export prices of electricity from PVT may be lower than the price of purchasing the electricity, even for net metering schemes. In this case, all PVT scenarios are not cost-effective and the need for a policy to maintain at least similar prices for the import and the export electricity is highlighted. 


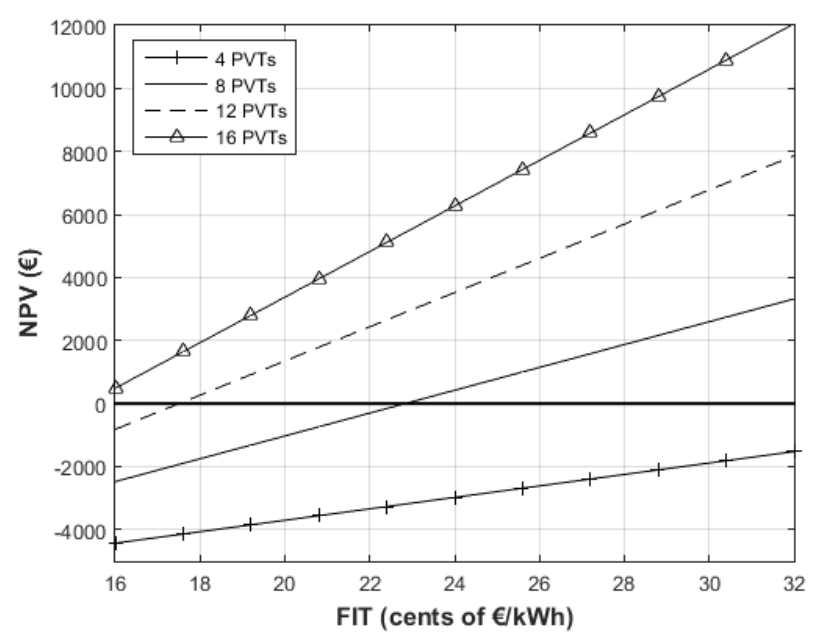

Figure 13.NPV achieved by the investigated PVT arrays as function of the FIT price.

The last case investigated in which the state can assist the economic viability of the SAGSHP systems is to subsidize the bank loan interest rate. The base case utilized bank loan interest rate has been set to $9 \%$ (Table 3), which is a representative value currently in Greece for that type and size of investments. In Figure 14, the NPV of the four sizes of PVT array is plotted as function of the bank loan interest rate. As it can be seen, the reduction of the bank loan interest rate is capable to benefit only the larger systems with 12 and 16 collectors. For the smaller PVT arrays, the 4 PVT array is never viable, and the array of 8 PVTs is only viable with bank interest rate less than $0.8 \%$. The array of 16 collectors is benefited more by the reduction of the loan interest rate, because it has the highest capital cost. As regards the larger array of 16 PVTs, this can be a more economic than the NGB system even with increased loan interest rate. Both Systems with the larger PVT arrays (12 and 16 collectors) can compensate a great amount of the consumed electricity, and by that, their viability lays more on factors related to their initial cost.

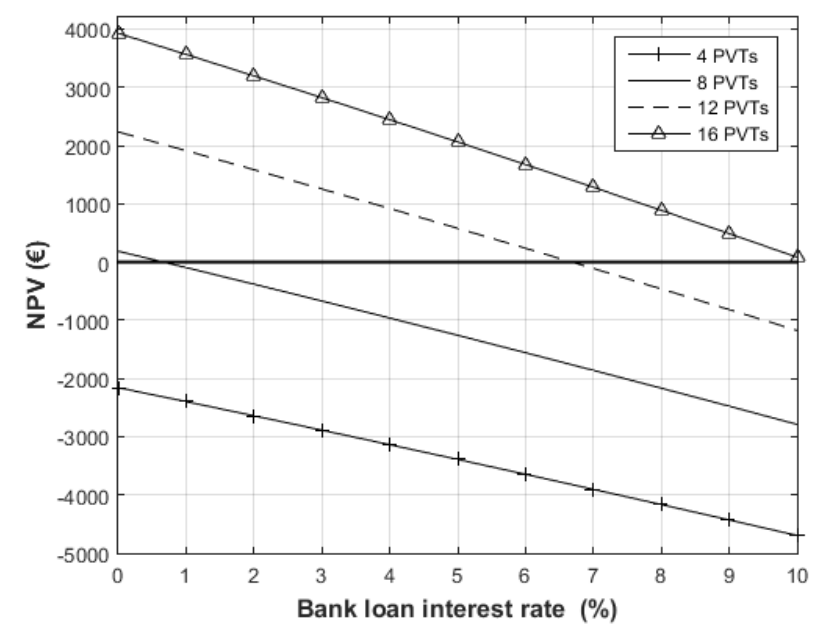

Figure 14. NPV achieved by the investigated PVT arrays as function of the bank loan interest rate.

As it is already mentioned, the ACOH can be used for the economical evaluation of the systems. The ACOH for all PVT arrays and for the NGB system are calculated via equation 12 and illustrated in Figure 15. Based on the results, the order of the achieved $\mathrm{ACOH}$ is identical to the order of the LCC illustrated by Figure 8. Thus, only the PVT array of 16 collectors was found to be better financial choice than the NGB system. In details, for the NGB system the cost per unit of load is $0.116 € \mathrm{kWh}^{-1}$ and for the SAGSHP with 16 PVTs slightly less, $0.113 €$ 
$\mathrm{kWh}^{-1}$. Also, the $\mathrm{ACOH}$ of the system with $4 \mathrm{PVTs}$ drops from $0.145 € \mathrm{kWh}^{-1}$ linearly as the array enlarges. Finally, one can say, that the ACOH of the SAGSHP systems is inversely related to their initial cost, higher cost lower $\mathrm{ACOH}$.

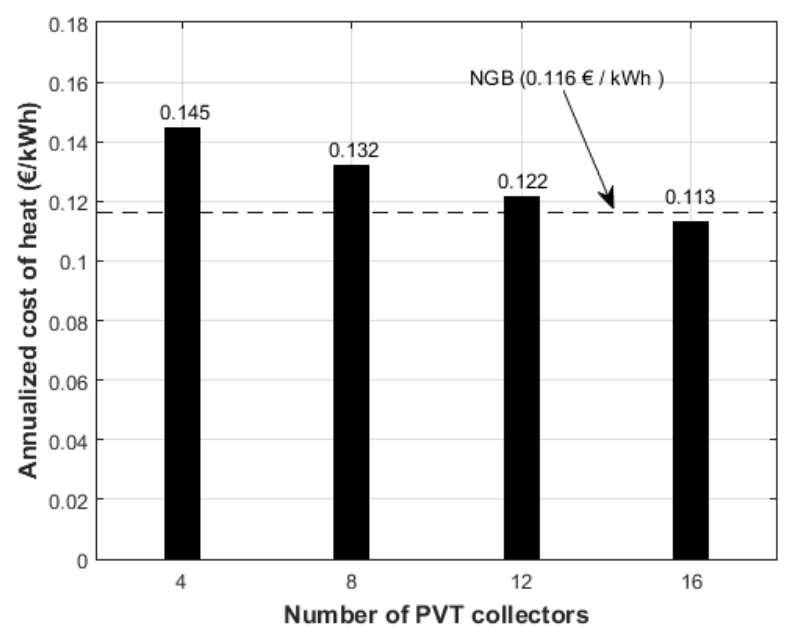

Figure 15. The annualized cost of heat for all PVT arrays of the SAGSHP system and for the NGB system.

\section{Conclusions}

In the present work, an energy and economic evaluation of a PVT-SAGSHP system was performed for a fully energy retrofitted dwelling in Thessaloniki (Greece). A mathematical model of the system formulated in TRNSYS was used for parametric analysis, by varying the number of PVT collectors. The SAGSHP system was assessed energetically by calculating seven energy metrics, while the system was compared financially against a natural gas boiler (NGB) via the life cycle cost method.

The heating load's fractional coverage from renewables (RHF) was estimated from 0.66 with the scenario of 4 PVT collectors, and up to 0.73 with 16 PVTs. Likewise, the proportion of system electricity fulfilled by the PVTs (RPF) was estimated from 0.28 up to 1.22 for the arrays of 4 and 16 collectors, respectively. RPF higher than one means a self-sufficient system, thus systems equipped with more than 14 collectors are capable to run totally on their own energy production on an annual basis. As regards the specific electrical yield of the PVTs, this was found insignificantly related to the number of PVT collectors. Through the analysis of the simulation results, a stagnation period regarding the solar heat absorption by the systems was estimated early in autumn. A solution on the stagnation issue can be a larger storage capacity (larger EEB) which may increase the solar heat utilization and consequently the energy performance of the system.

In the current study, the economics of SAGSHP system found to be related with the number of the PVT collectors. With detail, the system paired with 4, 8, and 12 PVT array scenarios was found to be uneconomic against the NGB system, but the case of 16 PVT collectors seems to be a superior economic solution. However, the scenarios of 4,8 , and 12 PVT collectors could become economically viable with government subsidy that could concern the economic parameters of: capital cost, FIT rates, and bank loan interest rate. The required subsidy to achieve economic viability is related to the number of the PVT collectors. Thus, with subsidy on system's capital cost from about $42 \%$ to $8 \%$, the PVT arrays of 4 and 12 collectors respectively, can be the best monetary solution. As regards the FIT rates, the scenarios of 8 can be economic viable by setting a rate higher than 23 cents of $€ \mathrm{kWh}^{-1}$, while for the array of 12 collectors an increase of just 1 cents of $€ \mathrm{kWh}^{-1}$ is adequate to be economic against the NGB system. The economic viability of the system with 4 PVTs cannot be obtained with any 
investigated FIT rate. Also, in the case of the net metering, PVT arrays with more than 14 collectors produce more electricity than the consumption and the surplus energy can be used to cover dwelling's appliances. The subsidy on the bank's loan interest rate, this found to benefit only the larger arrays of 12 and 16 collectors, while the viability for small arrays is controversial.

The economic viability of the proposed system depends significantly on its capital cost and the price of natural gas. Apart from that, the proposed system reduces the carbon emissions and it can be used to apply a more environmentally friendly policy. Lastly, by considering the Greek climatic conditions and the potential capital subsidy, the proposed SAGSHP system seems to be an attractive monetary and environmental investment.

\section{References}

[1] O. Ozgener, A. Hepbasli, A review on the energy and exergy analysis of solar assisted heat pump systems, Renew. Sustain. Energy Rev. 11 (2007) 482-496. https://doi.org/10.1016/j.rser.2004.12.010.

[2] M.S. Buker, S.B. Riffat, Solar assisted heat pump systems for low temperature water heating applications: A systematic review, Renew. Sustain. Energy Rev. 55 (2016) 399413. https://doi.org/10.1016/j.rser.2015.10.157.

[3] I. Sarbu, C. Sebarchievici, General review of ground-source heat pump systems for heating and cooling of buildings, Energy Build. 70 (2014) 441-454. https://doi.org/10.1016/j.enbuild.2013.11.068.

[4] E. Atam, L. Helsen, Ground-coupled heat pumps: Part 1 - Literature review and research challenges in modeling and optimal control, Renew. Sustain. Energy Rev. 54 (2016) 1653-1667. https://doi.org/10.1016/j.rser.2015.10.007.

[5] G. Nouri, Y. Noorollahi, H. Yousefi, Solar assisted ground source heat pump systems A review, Appl. Therm. Eng. 163 (2019). https://doi.org/10.1016/j.applthermaleng.2019.114351.

[6] A.G. Olabi, M. Mahmoud, B. Soudan, T. Wilberforce, M. Ramadan, Geothermal based hybrid energy systems, toward eco-friendly energy approaches, Renew. Energy. 147 (2020) 2003-2012. https://doi.org/10.1016/j.renene.2019.09.140.

[7] P.D. Metz, DEVELOPMENT OF A VALIDATED MODEL OF GROUND COUPLING, Present. Am. Sect. Sol. ENERGY Soc. 1980 Annu. Meet. - PHOENIX, ARIZONA JUNE 2-6,. (1980).

[8] L. Dai, S. Li, L. DuanMu, X. Li, Y. Shang, M. Dong, Experimental performance analysis of a solar assisted ground source heat pump system under different heating operation modes, Appl. Therm. Eng. 75 (2015) 325-333. https://doi.org/10.1016/j.applthermaleng.2014.09.061.

[9] B. Stojanović, J. Akander, Build-up and long-term performance test of a full-scale solarassisted heat pump system for residential heating in Nordic climatic conditions, Appl. Therm. Eng. $30 \quad$ (2010) 188-195. https://doi.org/10.1016/j.applthermaleng.2009.08.004.

[10] K. Bakirci, O. Ozyurt, K. Comakli, O. Comakli, Energy analysis of a solar-ground source heat pump system with vertical closed-loop for heating applications, Energy. 36 (2011) 3224-3232. https://doi.org/10.1016/j.energy.2011.03.011. 
[11] C. Naranjo-Mendoza, M.A. Oyinlola, A.J. Wright, R.M. Greenough, Experimental study of a domestic solar-assisted ground source heat pump with seasonal underground thermal energy storage through shallow boreholes, Appl. Therm. Eng. (2019) 114218. https://doi.org/10.1016/j.applthermaleng.2019.114218.

[12] P. Eslami-nejad, A. Langlois, S. Chapuis, M. Bernier, W. Faraj, Solar heat injection into boreholes, 4Th Can. Sol. Build. Conf. (2009) 237-246.

[13] Z. Han, M. Zheng, F. Kong, F. Wang, Z. Li, T. Bai, Numerical simulation of solar assisted ground-source heat pump heating system with latent heat energy storage in severely cold area, Appl. Therm. Eng. 28 (2008) 1427-1436. https://doi.org/10.1016/j.applthermaleng.2007.09.013.

[14] E. Kjellsson, G. Hellström, B. Perers, Optimization of systems with the combination of ground-source heat pump and solar collectors in dwellings, Energy. 35 (2010) 26672673. https://doi.org/10.1016/j.energy.2009.04.011.

[15] D. Carbonell, M.Y. Haller, E. Frank, Potential Benefit of Combining Heat Pumps with Solar Thermal for Heating and Domestic Hot Water Preparation, Energy Procedia. 57 (2014) 2656-2665. https://doi.org/10.1016/j.egypro.2014.10.277.

[16] V. Trillat-Berdal, B. Souyri, G. Fraisse, Experimental study of a ground-coupled heat pump combined with thermal solar collectors, Energy Build. 38 (2006) 1477-1484. https://doi.org/10.1016/j.enbuild.2006.04.005.

[17] E. Bertram, J. Glembin, G. Rockendorf, Unglazed PVT collectors as additional heat source in heat pump systems with borehole heat exchanger, Energy Procedia. 30 (2012) 414-423. https://doi.org/10.1016/j.egypro.2012.11.049.

[18] W. Yang, L. Sun, Y. Chen, Experimental investigations of the performance of a solarground source heat pump system operated in heating modes, Energy Build. 89 (2015) 97-111. https://doi.org/10.1016/j.enbuild.2014.12.027.

[19] D. Nicholson-Cole, Domestic Solar Earth Charging: modelling the process for augmentation of heat pump, CIBSE ASHRAE Tech. Symp. Imp. Coll. London UK - 18th 19th April 2012. (2012) 1-14.

[20] V. Verma, K. Murugesan, Experimental study of solar energy storage and space heating using solar assisted ground source heat pump system for Indian climatic conditions, Energy Build. 139 (2017) 569-577. https://doi.org/10.1016/j.enbuild.2017.01.041.

[21] A. Loose, H. Drück, Field test of an advanced solar thermal and heat pump system with solar roof tile collectors and geothermal heat source, Energy Procedia. 48 (2014) 904913. https://doi.org/10.1016/j.egypro.2014.02.104.

[22] A. Mehrpanahi, M. Arbabtafti, M.S. Karimi Dastenae, Extraction of optimal SAGSHP sizing based on the various control logic in specific climate condition, Sol. Energy. 190 (2019) 576-595. https://doi.org/10.1016/j.solener.2019.08.053.

[23] T. Sun, L. Yang, L. Jin, Z. Luo, Y. Zhang, Y. Liu, Z. Wang, A novel solar-assisted groundsource heat pump (SAGSHP) with seasonal heat-storage and heat cascade utilization: Field test and performance analysis, Sol. Energy. 201 (2020) 362-372. https://doi.org/10.1016/j.solener.2020.03.030.

[24] A.J. Wright, R. Talbot, M. Goddard, The solar house - a true low carbon solution for 2016?, in: CIBSE ASHRAE Tech. Symp., 2014: pp. 3-4. 
[25] C. Naranjo-Mendoza, R.M. Greenough, A.J. Wright, Are shallow boreholes a suitable option for inter-seasonal ground heat storage for the small housing sector?, Conf. IGSHPA. (2018) 1-10. https://doi.org/10.22488/okstate.18.000040.

[26] M. Bakker, H.A. Zondag, M.J. Elswijk, K.J. Strootman, M.J.M. Jong, Performance and costs of a roof-sized PV/thermal array combined with a ground coupled heat pump, Sol. Energy. 78 (2005) 331-339. https://doi.org/10.1016/j.solener.2004.09.019.

[27] Solar Energy Laboratory University of Wisconsin-Madison, GmbH - TRANSSOLAR Energietechnik, CSTB - Centre Scientifique et Technique du Bâtiment, TESS - Thermal Energy Systems Specialists, TRNSYS 17 - a TRaNsientSYstem. Simulation program, Simulation. (2009).

[28] M. Baetschmann, H. Leibundgut, LowEx Solar Building System: Integration of $P V / T$ Collectors into Low Exergy Building Systems, Energy Procedia. 30 (2012) 1052-1059. https://doi.org/10.1016/j.egypro.2012.11.118.

[29] G. Emmi, S. Bordignon, A. Zarrella, M. De Carli, A dynamic analysis of a SAGSHP system coupled to solar thermal collectors and photovoltaic-thermal panels under different climate conditions, Energy Convers. Manag. $213 \quad$ (2020). https://doi.org/10.1016/j.enconman.2020.112851.

[30] J. Huang, J. Fan, S. Furbo, Demonstration and optimization of a solar district heating system with ground source heat pumps, Sol. Energy. 202 (2020) 171-189. https://doi.org/10.1016/j.solener.2020.03.097.

[31] N. Sommerfeldt, H. Madani, In-depth techno-economic analysis of PV / Thermal plus ground source heat pump systems for multi-family houses in a heating dominated climate, Sol. Energy. 190 (2019) 44-62.

[32] F.M. Rad, A.S. Fung, W.H. Leong, Combined solar thermal and ground source heat pump system, IBPSA 2009 - Int. Build. Perform. Simul. Assoc. 2009. (2009) 2297-2305.

[33] F. Ochs, G. Dermentzis, W. Feist, Minimization of the residual energy demand of multistorey Passive Houses - Energetic and economic analysis of solar thermal and PV in combination with a heat pump, Energy Procedia. 48 (2014) 1124-1133. https://doi.org/10.1016/j.egypro.2014.02.127.

[34] H. Weeratunge, J. De Hoog, S. Dunstall, G. Narsilio, S. Halgamuge, Life Cycle Cost Optimization of a Solar Assisted Ground Source Heat Pump System, IEEE Power Energy Soc. Gen. Meet. 2018-Augus 1-5. https://doi.org/10.1109/PESGM.2018.8586063.

[35] C. Tzivanidis, E. Bellos, G. Mitsopoulos, K.A. Antonopoulos, A. Delis, Energetic and financial evaluation of a solar assisted heat pump heating system with other usual heating systems in Athens, Appl. Therm. Eng. 106 (2016) 87-97. https://doi.org/10.1016/j.applthermaleng.2016.06.004.

[36] Y. Zhu, Y. Tao, R. Rayegan, A comparison of deterministic and probabilistic life cycle cost analyses of ground source heat pump (GSHP) applications in hot and humid $\begin{array}{lllll}\text { climate, } & \text { Energy } & \text { Build. } & 55 & \text { (2012) }\end{array}$ https://doi.org/10.1016/j.enbuild.2012.08.039.

[37] B. Agrawal, G.N. Tiwari, Life cycle cost assessment of building integrated photovoltaic thermal (BIPVT) systems, Energy Build. 42 (2010) 1472-1481. https://doi.org/10.1016/j.enbuild.2010.03.017. 
[38] W. Short, D. Packey, T.H. Nrel, A Manual for the Economic Evaluation of Energy Efficiency and Renewable Energy Technologies A Manual for the Economic Evaluation of Energy Efficiency and Renewable Energy Technologies, (2016). https://doi.org/10.2172/35391.

[39] B.S. Dhillon, Life Cycle Costing for Engineers, 2009. https://doi.org/10.1201/9781439816899.

[40] J.A. Duffie, W.A. Beckman, Solar Engineering of Thermal Processes: Fourth Edition, 2013. https://doi.org/10.1002/9781118671603.

[41] P.J. Axaopoulos, E.D. Fylladitakis, Performance and economic evaluation of a hybrid photovoltaic/thermal solar system for residential applications, Energy Build. 65 (2013) 488-496. https://doi.org/10.1016/j.enbuild.2013.06.027.

[42] M. Herrando, C.N. Markides, Hybrid PV and solar-thermal systems for domestic heat and power provision in the UK: Techno-economic considerations, Appl. Energy. 161 (2016) 512-532. https://doi.org/10.1016/j.apenergy.2015.09.025.

[43] B. Bourges, European simplified methods for active solar system design, 1991.

[44] E.I. Sakellariou, P.J. Axaopoulos, Energy performance indexes for solar assisted ground source heat pump systems with photovoltaic-thermal collectors, Appl. Energy. 272 (2020) 115241. https://doi.org/10.1016/j.apenergy.2020.115241.

[45] H.E. Beck, N.E. Zimmermann, T.R. McVicar, N. Vergopolan, A. Berg, E.F. Wood, Present and future köppen-geiger climate classification maps at 1-km resolution, Sci. Data. 5 (2018) 1-12. https://doi.org/10.1038/sdata.2018.214.

[46] M. Kottek, J. Grieser, C. Beck, B. Rudolf, F. Rubel, World map of the Köppen-Geiger climate classification updated, Meteorol. Zeitschrift. 15 (2006) 259-263. https://doi.org/10.1127/0941-2948/2006/0130.

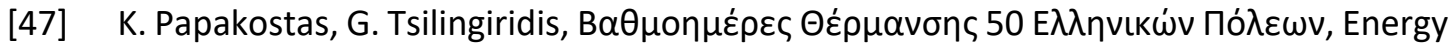
Perform. Build. (2014) 50-65. https://doi.org/10.1007/978-3-319-20831-2.

[48] E.I. Sakellariou, A.J. Wright, P. Axaopoulos, M.A. Oyinlola, PVT based solar assisted ground source heat pump system : Modelling approach and sensitivity analyses, Sol. Energy. 193 (2019) 37-50. https://doi.org/10.1016/j.solener.2019.09.044.

[49] E. Sakellariou, P. Axaopoulos, An experimentally validated, transient model for sheet and tube PVT collector, Sol. Energy. 174 (2018) 709-718.

[50] G. Hellström, Duct Ground Heat Storage Model, Manual for Computer Code, Energy. (1989). TESS type 557.

[51] Eurostat, People in the EU - statistics on an ageing society, Stat. Explain. (2015) 1-20. http://ec.europa.eu/eurostat/statistics-

explained/index.php/People_in_the_EU_?_statistics_on_household_and_family_stru ctures\#Household_composition:_number_of_persons.

[52] Technical Chamber of Greece, Technical Directive 20701-1: National Specifications of Parameters for Calculating the Energy Performance of Buildings and the Issue of the Energy Performance Certificate, (2017).

[53] A.G. Gaglia, E.N. Dialynas, A.A. Argiriou, E. Kostopoulou, D. Tsiamitros, D. Stimoniaris, K.M. Laskos, Energy performance of European residential buildings: Energy use, technical and environmental characteristics of the Greek residential sector - energy 
conservation and $\mathrm{CO}_{2}$ reduction, Energy Build. 183 (2019) 86-104. https://doi.org/10.1016/j.enbuild.2018.10.042.

[54] European Parliament, Decision (2013/114/EU) Establishing the Guidelines for Member States on Calculating Renewable Energy from Heat Pumps from Different Heat Pump Technologies pursuant to Article 5 of Directive 2009/28/EC of the European Parliament an dof the Council, Off. J. Eur. Union. (2016) 27-35. 